\title{
THE IMPORTANT OF MANDATORY CONSULAR NOTIFICATION BETWEEN INDONESIA AND OTHER FOREIGN STATES
}

\author{
Amelya Gustina* \\ Pusat Penelitian dan Pengembangan Kejaksaan Agung Republik Indonesia, Jakarta \\ Jalan Sultan Hasanudin Nomor 1, Kebayoran Baru, Jakarta Selatan, D.K.I. Jakarta 12160
}

\begin{abstract}
The advancement of globalization, cause the high rate of migration people from one nation to another nations. They come for many activities that might cause problems for them in the destination countries that make them arrested or detention. Realizing this condition many country establish consular relation by ratified VCCR 1963. In spite of it, there are still many cases not related to that cconvention. The method used is the juridical-normative with qualitative-descriptive approach. The result of paper reveals that the importance of Mandatory Consular Notification (MCN) is to optimalize the protection of Indonesia citizens in abroad.
\end{abstract}

Keywords: MCN, consular, relation, Indonesia.

\section{Intisari}

Kemajuan globalisasi, menyebabkan tingginya tingkat migrasi orang dari satu negara ke negara lain. Mereka datang untuk berbagai aktivitas yang mungkin menyebabkan masalah di negara tujuan yang membuat mereka ditangkap atau ditahan. Menyadari kondisi ini banyak negara membangun hubungan konsuler dengan meratifikasi Konvensi Wina tentang Hubungan Konsuler 1963. Terlepas dari itu, masih banyak kasus warga tidak terkait dengan konvensi tersebut. Metode penelitian yang digunakan adalah yuridis normatif dengan pendekatan deskriptif kualitatif. Hasil dari tulisan ini mengungkapkan bahwa pentingnya Persetujuan Notifikasi Konsuler (Mandatory Consular Notification/MCN) untuk mengoptimal perlindungan terhadap warga negara kita di luar negeri.

Kata Kunci: MCN, konsuler, hubungan, Indonesia.

\section{Pokok Muatan}

A. Background 322

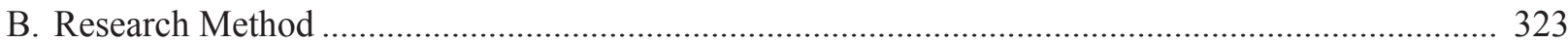

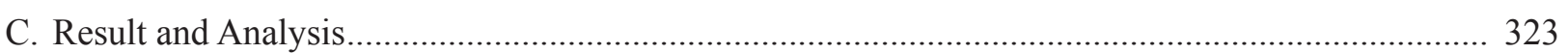

1. Consular Relations and Consular Notifications: Theoretical Perspective ................................... 323

2. The Importance of Mandatory Consular Notification (MCN) for Consular Relation

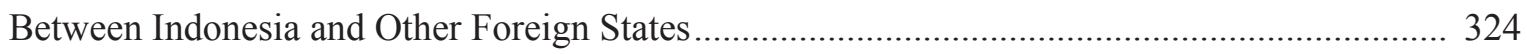

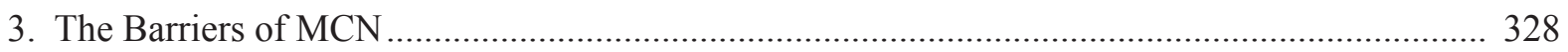

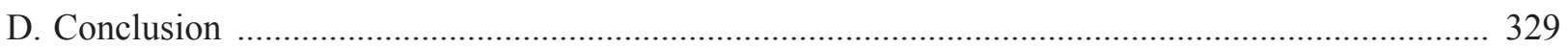




\section{A. Background}

With the advancement of globalization, the rate of migration of people from one nation to another nation is getting higher. This might result in causing the problems for those migrating people in the destination countries. Most of these problems related to the violation of the destination state immigration rules for example, illegal entry, forget passport, and so forth. The differences of cultural background, norm and customary between extraction state to the destination state are some factor that make problems for the aliens. These problems could be public or private. ${ }^{1}$

Because of it, each citizen needs some protection from his or her States. Providing protection to its citizens who are coping with problems abroad is one of the state's obligations. Fulfilling this specific obligation is not a simple task for State. Therefore, all states should put high priority to this duty. Including Indonesia as one of state, that has many citizens who were living and working abroad. On preamble of the 1945, Constitution of the Republic of Indonesia and Article 19 (b) Act Number 37 of 1999 on Indonesia Foreign Relations said that State has responsibility to protect the honor and possessions of Indonesian citizens who are living abroad. This constitution and act are relevant as ponder for our government, especially in economic globalization context, which are many of Indonesian citizens working and living abroad. ${ }^{2}$ Besides that, there are 4 (four) priority of Indonesian policy, defacing the unity of Indonesia, recovering the national economic, recovering Indonesian image, and giving the protection for Indonesian citizens in abroad. ${ }^{3}$ Clearly, protection to the citizens is a big problem and need high priority.
Because of those problems, there are so many countries establish the consular relation with other country around the world. ${ }^{4}$ In dealing with this matter, most state refer to the existing international convention such as the 1961 Vienna Convention on Diplomatic Relation as well as the 1963 Vienna Convention on Consular Relation (referred to hereafter as the "VCCR" or the "treaty"), has ratified by Indonesia on Act Number 1 of 1983. This Vienna Convention guarantees consular official of each nations that has adopted it access (consular access) to their nationals who may need assistance when traveling, working, or living abroad. Consular access founded in Article 36 of the Vienna Convention on Consular Relation 1963. This Article stated communication and contact with nationals of the sending state. On the other hand, Article 36 of the VCCR establishes mechanisms by with consular officer may assist their citizens as soon as possible who have been arrested or detained in another country that has accepted the VCCR. ${ }^{5}$

In spite of it, there are still many cases not related to Article 36 of the VCCR cause until this time, we are still see and hear many of our citizens get many problems in abroad but they are still late get an accesses for their protections. Optimal the protection for them there need study about The Importance of Mandatory Consular Notification (MCN) for Consular Relations between Indonesia and Other Foreign States. This writing aims is to give information about The Importance of Mandatory Consular Notification $(\mathrm{MCN})$ for Consular Relations between Indonesia and Other Foreign States with a different of view. And also this writing will hopefully be useful for the writer, organs related to this subject and for the

\footnotetext{
Djoko Hardono, "Perlindungan Warga Negara dalam Perbandingan", Jurnal Hukum International, Fakultas Hukum Universitas Indonesia, Vol. 30, No. 1, 2003, p. 28

Sukanda Husin, "Perlindungan Hukum Tenaga Kerja Indonesia (TKI) di Luar Negeri", Papers, Present on Socialization of Law Protection for WNI and BHI in Foreign Countries, Padang, 12 September 2006, p. 1.

N. Hassan Wirayuda, "Refleksi 2003 dan Proyeksi 2004 Departemen Luar Negeri Republik Indonesia", http://www.kbri-canberra.org.au/ speeches/2004/040106menlu.htm, accessed on 21 July 2012.

B. Sen, 1979, A Diplomat's Handbook of International Law and Practice, Martinus Njhoff Publishers, London, pp. $227-244$.

John Cary Sims and Linda E. Carter, "Representing Foreign Nationals: Emerging Importance of The Vienna Convention on Consular Relations as a Defence Tool", http://www.nacdl.org/CHAMPION/ARTICLES/98sep01.htm, accessed on 10 July 2012.
} 
development of knowledge.

\section{B. Research Method}

Problems approach is done through normative study research or law research, with assisted by empirical data (the primary law substances in addition to the secondary and tertiary law substances) to support research. The substances are descriptively analyzed.

\section{Result and Analysis \\ 1. Consular Relations and Consular Notifications: Theoretical Perspective}

Consular relations had been established between people since ancient time than diplomatic relation. For the first time, diplomatic and consular relation base on customary law. Especially for consular relation for the first time, the regulation of the consular relations base on bilateral agreement between states, which has done the consular relations. To complete this agreement most country made national act using by national court. After that, customary law was used.

However, in 1955 International Law Commission (ILC) decided to codify the determinate of International Law concern the consular relations. As a result, in 1961 The General Assembly of the United Nations decided to hold a codification conference in Vienna 1963. This conference has fallow up of the acceptance of the convention on Diplomatic Relations 1961. In addition, on 24 April 1963 Conventions on Consular Relations was born and was prevail on March 1967.In that convention we know about consular notification and access that will have relationship with MCN.

By interpretation the Articles 36 on Vienna Conventions on Consular Relations 1963 the definitions of consular notifications are: ${ }^{6}$ (1) A consular notification is a notification that inform to the official of the receiving States to the consular

N. Hassan Wirayuda, Op.cit., p.1.

Article 37 of Vienna Convention on Consular Relation 1963. officer of the sending States about the arrest and detentions of their national in that constituency; (2) A consular notification is facilities that give by international law to the consular officer of the sending States and national to communicate in the receiving States; and (3) A consular notification is a right of nationals who are arrest and detentions to get assistance from their consular offices.

From these definitions, conclude that consular notification is a formal announcement of fact or actions about consular. Consular notification is not always for arrested or detention citizens but also for deaths, guardianship or trusteeship, wrecks and air accidents, birth, and insurance. ${ }^{7}$

The principles of Consular Notifications are:

a. Must be informing about the right of the citizens who are arrest or detentions to get assistance and consular access.

b. Without delay. Generally, after determine the citizenships of those citizens who is arrest or detentions before the investigations inform his/ her right to get consular access from the consular offices or representatives of their country.

c. Reciprocity. Entitled office must in no doubt that, consular notifications have done, if the citizen arrested or detentions get same treatment. It was Department Foreign Affair and Directorate for The Protection of Indonesian Citizens and Legal Entities job.

In Indonesia, consular notifications are regulated on Criminal Code of Conduct Number 8 of 1981 (Kitab Undang-Undang Hukum Acara Pidana No. 8 Tahun 1981), Articles 57(1) \& (2), Articles 59, 60, 61, 62 (1), (2) \& (3). There also Act Number 1 of 1982 about the ratification of Vienna Convention on Consular Relations 1963 (Undang-Undang Nomor 1 Tahun 1982 tentang Ratifikasi Konvensi Wina 1963). The International Law, consular notifications can see in United Nations Instruments, Vienna 
Convention on Consular Relation 1963 Article 36 and other conventions such as, Article 16 point 7 International Convention on the Protection of the Rights of All Migrant Workers and Members of Their Families 1990, Part I No. 38 Contact with the Outside, World Standard Minimum Rules for the Treatment of Prisoners etc.

Mandatory Consular Notification (MCN) is an agreement between the sending States and receiving States about consular notification. ${ }^{8}$ This mandatory is a way to maximize the realization of consular notification which respectable procedure and more detail than arrangement on Vienna Conventions on Consular Relation 1963. As we know, consular notification have 3 (three) principles, and also mandatory consular notification. There are: ${ }^{9}$

a. Obligatory

Regardless of foreign national's wishes who is arrest or detention without delay.

b. This is based on the agreement between sending States and receiving States (after or before investigation)

c. Reciprocity Principles

The qualified officer has conviction that consular notification has been do if the national have same treatment when his/her arrested or detention.

With these mandatory consular notifications, consular notification became obligatory. Notify consular officials of country of citizenship without delay, of the arrest/detention, regardless of foreign national's wishes. These MCN has difference roles with Vienna Convention on Consular Relation Article 36 stated that consular notification is optional base on the foreign national's wishes to notify or not his/her consular officials.

The Act Number 24 of 2000 on International Treaties becomes an umbrella for the government to conclude an agreement with a foreign country, if it is necessary, to protect the interests of its citizens abroad. For instance, as a response to enormous problems faced by Indonesian migrant workers, Indonesian and Malaysian Government signed the first MoU in 1998 and the second one on May 10, 2004, to govern labor migration. Both MoUs specifically covers migrant workers in construction, factories and plantation but exclude domestic worker. ${ }^{10}$

There also Act Number 1 of 1982 about the ratification of Vienna Convention on Consular Relations 1963 (Undang-Undang Nomor 1 Tahun 1982 tentang Ratifikasi Konvensi Wina 1963). The regulation of MCN is base on customary law (International customary law) and Vienna Conventions on Consular Relation 1963 Article 73 paragraf 2 stated:11 "Nothing in the present convention shall preclude States from concluding international agreements confirming or supplementing or extending or applying the provisions there of'. From this article, conclude that bilateral and multilateral agreement about consular relation allowed by international law since it just confirmations, supplement, addition and expansion from Vienna Conventions on Consular Relation 1963. ${ }^{12}$

\section{The Importance of Mandatory Consular Notification (MCN) for Consular Relation Between Indonesia and Other Foreign States}

Mandatory consular notification comes from the United States for the first time. The backgrounds of establishment MCN are LaGrand Case (USA vs German) and Angel Breard Case (USA Vs Republic of Paraguay). La Grand case happened in 1984. Walter and Karl LaGrand, both German nationals, sentenced to death in Arizona for murder of bank

\footnotetext{
Departemen Luar Negeri Direktorat Perlindungan WNI-BHI, "Mandatory Consular Notification", Papers, presented on Socialization of Law Protection for WNI and BHI in Foreign Countries, Padang, 12 September 2006, p, 1.

10 Rofita, “A Concept for The Protection of Indonesian Citizens and Properties Abroad”, Papers, Mid Level Diplomatic Course Batch XXXV Centre for Education and Training Department of Foreign Affairs Republic Indonesia, Jakarta, 15 Mei 2006.

1 Article 73 paragraf 2 of Vienna Conventions on Consular Relation 1963.

12 Suryonokusumo, 1995, Hukum Diplomatik Teori dan Kasus, Alumni, Bandung, p. 26.
} 
manager during an attempted robbery. When Arizona officials arrested the LaGrand brother, they did not inform them of their right to consular notification and access. ${ }^{13}$

Moreover, Angel Breard case happened on September 1, 1992. Police officer in Virginia arrested Angel Breard, a Paraguayan national, on suspicion of attempted rape and murder. Although the arresting officers knew that Breard was Paraguayan citizen, they did not inform him of his right to communicate with and receive assistance from the Paraguayan government. Realize with that condition USA made such a bilateral agreement called Mandatory Consular Notification. Until this time, USA has MCN with 54 States in the world.

And Indonesia as a country which have many citizens who are living, working and having education abroad, regard the importance of making $\mathrm{MCN}$ with the distinction country. MCN will give guarantee for respectable procedure of consular notification because not all country, which has ratified Vienna Convention on Consular Relation 1963 article 36 about communication and contact with nationals of sending States. It makes our citizens cannot get consular access from consular officer as son as possible (without delay). For examples are cases of Indonesian maid in abroad. Many of them get problems, accident, and violations or do criminal. From that condition, they need assistance from consular officer. In fact, still many of receiving States late to inform or do not inform our consular representatives offices about this problems.

Consular notification become mandatory if there is a treaty provision that in effect between two countries. A consular officer shall be notified, without reference to a demand or request of the arrested citizen, even if the arrested person asked that he/s not be notified. Consular notification not only can help to ensure the Indonesian Government's ability to protect its citizens but also can prevent needless litigation and legal challenges that can threaten prosecution cases.

Consular relations have some function that are very varied indeed and include the protection of the interests of the sending state and it's national. There are: ${ }^{14}(a)$ protecting in the receiving state the interest of the sending state and of its national, both in individuals and bodies corporate, within the limits permitted by international law; (b) furthering the development of commercial, economic, cultural, and scientific relations between the sending state and the receiving state; (c) ascertaining by all lawful means conditions and developments in the commercial, economic, cultural and specific life of the receiving state; (d) issuing passports and travel documents to nationals of the sending state, and visas or appropriate documents to persons wishing to travel to sending state; (e) helping and assisting national; (f) acting as notary and civil registrar and in capacities or a similar kind, and performing certain functions of an administrative nature; (g) safeguarding the interests of nationals; (h) safe guarding, within the limits imposed by the laws and regulations of the receiving state; (i) subject to the practices and procedures obtaining in the receiving state, representing of arranging appropriate representation for nationals of sending state before the tribunals and other authorities of the receiving state; (j) transmitting judicial and extrajudicial documents or executing letters or commissions; ( $\mathrm{k}$ ) exerting rights of supervision and inspection provided for the laws and regulations of the sending state in respect of vessels the nationality of the sending state; (1) extending assistance to vessels and aircraft to their crews; (m) performing any other functions.

After get consular notifications the citizens will get consular access. The Right of Consular Access are: ${ }^{15}$

\footnotetext{
Cindy Galway Buys, et al., "Do Unto Others: The Importance of Better Compliance with Consular Notification Rights", Duke Journal of Comparative \& International Law, Vol. 21, No. 461, 2011, p. 486

14 Shaymin Ak., 1998 , Hukum Diplomatik Suatu Pengantar, Armico, Bandung, p. 111

15 Article 36 Vienna Convention on Consular Relations 1963.
} 
1. Consular visits. Under circumstances requiring notification, or when a foreign national is confined in a military confinement facility, the consul shall, upon proper identification to the notifying officer, have the right to visit the foreign national immediately. Such visits shall be conducted in accordance with confinement facility regulations, which shall permit reasonable access to, and the opportunity of privately conversing with, the foreign national. The consul shall be allowing, subject to confinement facility regulations, to transmit communications between the prisoner and other persons.

2. To be communicate between consul and foreign national. Whether or not a foreign national is confined, he shall have a right to communicate either orally, including telephonically, or in writing with consul and receive such communications from the consul. All such communications shall be treated as privileged and not subject to inspection or monitoring, except in those exceptional cases in which the notifying officer determines that national security considerations are involved.

3. And other consular rights. The consul shall given full opportunity to safeguard the interests of the foreign national concerned. The consul has the right to confer with, to interview, to advice, to arrange legal representation for, to make inquiries to incidents affecting the interest of, and to other assist of foreign nationals, the consul or other official representative of the foreign country shall be treated with the dignity and courtesy befitting his office.

This is a diagram show the procedure of consular notification for arrested or detention foreign national (Figure 1).
Figure 1. Procedure of Consular Notification

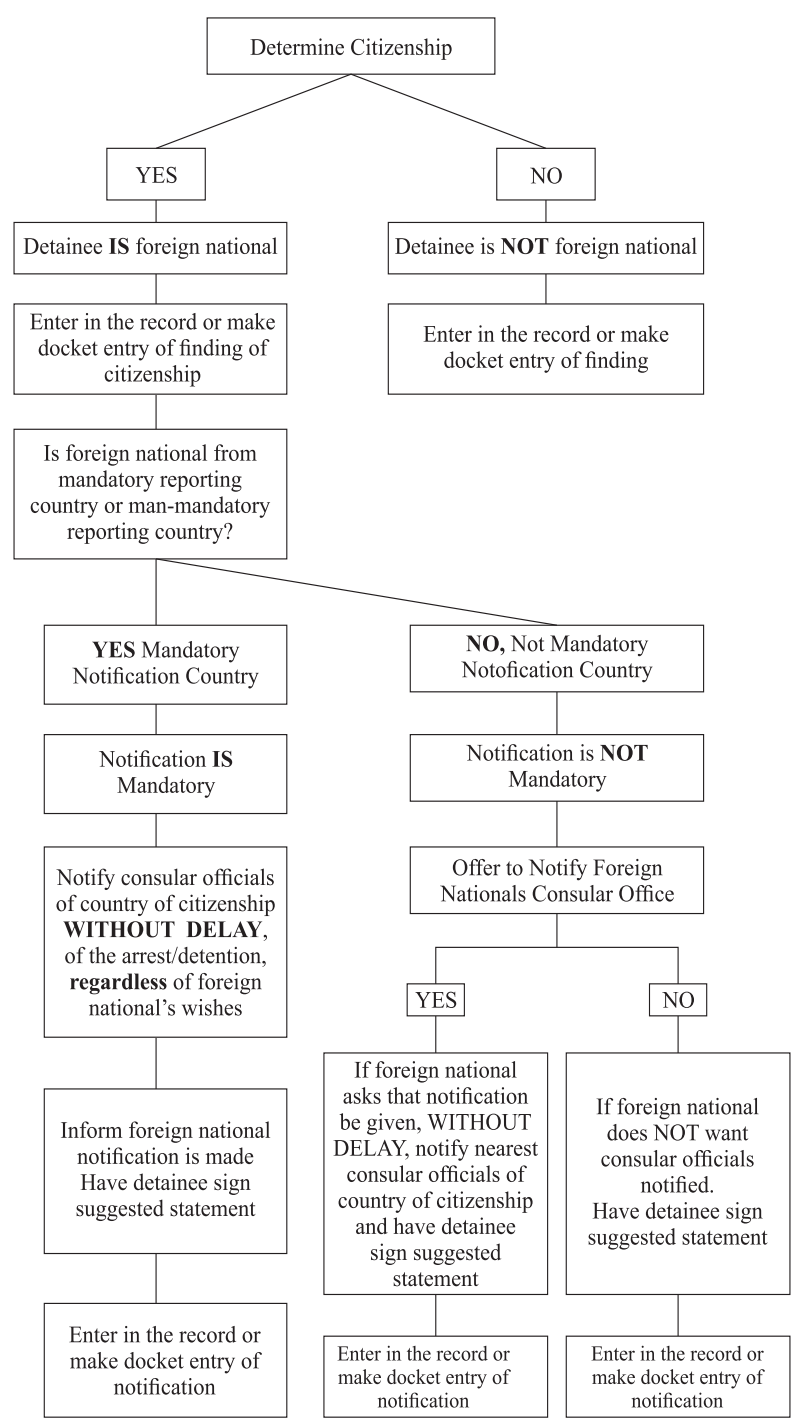

Source: Department Foreign Affairs Republic of Indonesia.

From the diagram, conclude that steps to follow when a foreign national is arrested or detained are:

1. It is imperative that the determination of citizenship be on the record. Courts of record should ensure that the court reporter records all information regarding determination of citizenship, advisement or rights, and actions taken. Courts not of record should record in the docket all information establishing citizenship, including the responses of the defendant, advisement or 
rights, and actions taken. In addition, warning forms should include Vienna Convention warnings in the event that a foreign national is arrested or detained.

2. Determine the defendant's citizenship. This can be established by asking place of birth of the defendant, whether the defendant was born out of the receiving states. In the absence of other information to the contrary, assume this is the country on whose passport or other travel document the foreign national travels.

3. If the foreign national's country of citizenship is not on the mandatory notification list on the next section:

(a) Offer without delay, to notify the foreign national's consular officials of the arrest/detention. ${ }^{16}$

(b) If the foreign national asks that the consular notification be given, notify the nearest consular officials of the foreign national's country of citizenship without delay. For phone and fax numbers to foreign embassies and consulates in the receiving states.

4. If the foreign national's country of citizenship is on the list of mandatory notification countries on the next section:

(a) Notify that country's nearest consular officials, without delay, of the arrest/detention regardless of the foreign national's wishes. Phone and fax numbers for the mandatory countries.

(b) Inform the foreign national that you are making this notification.

Realizing with this condition, Indonesia think that having a MCN with other country is more effective to give an access as a form of protection for our citizens in other foreign country around the world. Under Minister of Foreign Affair Decree No. SK.582/BU/III/79/01/TH. 79 on the Representatives Structure of the Republic of Indonesia in Abroad (Keputusan Menteri Luar Negeri Republik Indonesia Nomor: SK.582/BU/III/79/01/TH 79 tentang Susunan Organisasi Perwakilan-Perwakilan Republik Indonesia di Luar Negeri), we know that there are two of Indonesian representatives offices abroad. They are diplomatic representatives and consular representatives. ${ }^{17}$

This representative has high function for diplomatic and consular relations. Embassy of the Republic of Indonesia is one of the representatives' bases on Minister of Foreign Affair decree No: SK.00705/OR/VII/81/)1 on General Job System of The Representatives of The Republic of Indonesia in Abroad (Keputusan Menteri Luar Negeri Republik Indonesia Nomor: SK.00705/OR/VII/81/01 tentang Tata Kerja Umum Perwakilan Republik Indonesia di Luar Negeri). Because of that in 2000 Department of Foreign Affairs express to make MCN with other country. Nevertheless, they have processed it in 2002. In addition, in $2005 \mathrm{MCN}$ be present in Daftar Isian Pelaksanaan Anggota (DIPA). Until this time, Indonesia has make bargaining $\mathrm{MCN}$ to over 15 countries such as Dutch, Australia, United States, Greece, Malaysia, Qatar, Jordan, Saudi Arabia, Australia, and Canada. ${ }^{18}$

From that diagram, conclude that Indonesia has strategic position for bargain MCN as sending States with border or suborder states. Some of that states has an MCN with some states such as US and Canada. However, the problems is, the reciprocity principles that use in $\mathrm{MCN}$, can Indonesia do consular notification as well as that other States

16 Art. 36 par. 1, Vienna Convention on Consular Relation 1963.

17 Art. 1 Keputusan Menteri Luar Negeri Republik Indonesia Nomor: SK.582/BU/III/79/01/TH 79 tentang Susunan Organisasi PerwakilanPerwakilan Republik Indonesia di Luar Negeri.

18 This data was accessed from Department Foreign Affairs Republic of Indonesia, Directorate for the Protection of Indonesian Citizens and Legal Entities. 


\section{Figure 2. Objective Country of MCN}

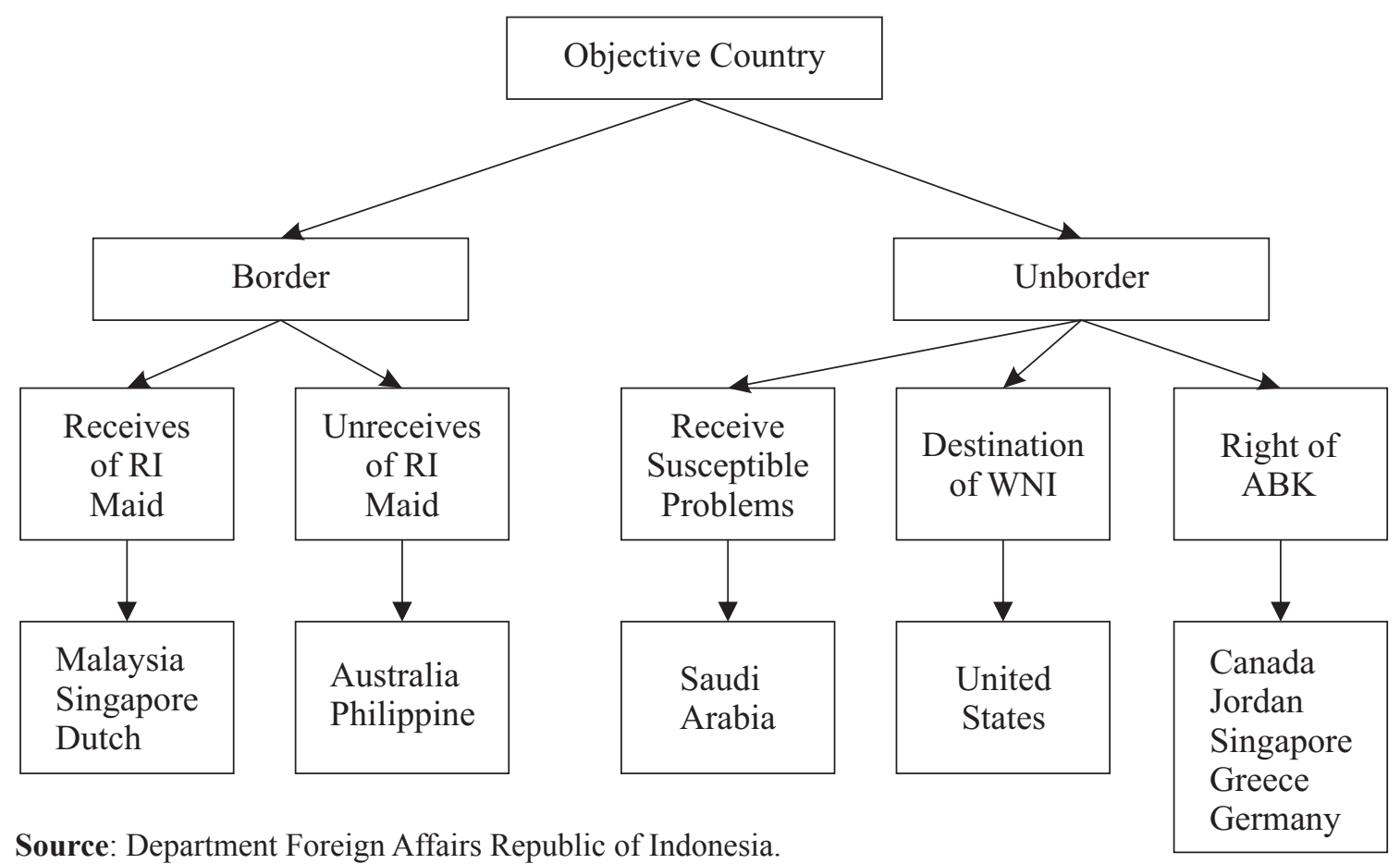

done? There are some factor may make reciprocities principles between Indonesia and other States can work well, they will be explaining next.

\section{The Barriers of $\mathrm{MCN}$}

Talking about MCN also related to receiving States and sending States. Work or do not work the process of MCN related to both of this. And because $\mathrm{MCN}$ is an international convention (bilateral agreement) they are same principles of international conventions such as the reciprocity principles and good faith there are:

a. The Reciprocity Principles

The reciprocity principles become the barriers of MCN because the qualified officer has conviction that $\mathrm{MCN}$ has been do if the national have same treatment when his/her get consular problems. And because MCN is a new thing for Indonesia, I assume that reciprocity principles become big barriers to make a MCN with other country, Indonesia may be does not have good bargaining position root to:

(1) The Indonesian geography, which is large and separate by sea and island. Three different

times for three part of that location. It makes difficulties in giving information to one place to other because the telecommunication technology of Indonesia still undeveloped appeal with the geography.

(2) The unready of Indonesian officer about MCN and its reciprocity principles. Realizing MCN, consular notification and access is something new for Indonesia, not all officers know about this at all. For example, the police in village of West Sumatra must do know about consular notification because there must no explanation and information's about it before.

c) The bad of Data collection systems of foreign citizens in Indonesia. Not all foreign citizens who came to Indonesia can be encoding for processing because the data collection systems that long and twins in and out. 
b. Good Faith

Because $\mathrm{MCN}$ is international convention (bilateral agreement), good faith is also importance point. If both countries do not do MCN as well as them unanimously, MCN will not work well too. For examples, Malaysia still gives bad treatment for our citizens there even though we had MoU about Indonesian and Malaysian Government signed the first $\mathrm{MoU}$ in 1998 and the second one on May 10, 2004, to govern labor migration.

c. There is no Act about the protections especially for our manpower in foreign country. This act should regulate by details all about the manpower in foreign country start from departure until they are arrive in the destination state. Because the Act that we have now, just only talking about domestic manpower. And fact stated that we get so many problems about our manpower in foreign country.

d. Not all our officers in foreign country do their duty as citizen's services. Take a long time and twins in and out to get a citizen's service make our citizens decided does everything by them selves without confirm the Indonesia Embassy in that State.

e. The difference of legal systems between Indonesia and other foreign country cause difference comprehension about points in MCN.

\section{Conclusion}

Consular relations had been established between people since ancient time than diplomatic relation. And in 1963 consular relation become international convention call Vienna Convention on Consular Relation 1963. Vienna Convention 1963 is also talking about consular notification and access (article 36). In international relations our consul need consular notification to give an access for their citizens if they get some problems there. Consular notification and access is a form of citizen's protection.
In spite of it, there are still many cases not related to Article 36 of the VCCR. Because of that problem, we need other instrument of international law called MCN. MCN comes from the United States for the first time. The backgrounds of establishment MCN are LaGrand Case (USA Vs German) and Angel Breard Case (USA Vs Republic of Paraguay). MCN is one of good point to solve the problems of Indonesia citizens abroad. Events though it's still many barriers in making MCN between Indonesia and other foreign states. And socialization and good diplomacy are same solution of that problem.

From the summary that we get, there are some sugestion that might to realization, there are: Firstly, consular notification and access is a form of protection for Indonesian citizen abroad. Realize with that condition, receiving states, sending states and its citizens should know about the duty, obligatory and right each of them. So, MCN as continuation of consular notification and access can work well; Secondly, socialization is base point that Indonesia should do to solve the barrier of MCN. There should be readiness from Indonesian government to have Mandatory Consular Notification (MCN) with other States. It can be by socialize the importance of and information about consular notifications to qualified officer such as police officer, immigration officer, customs officer, penitentiary officer, and airport and harbor officer; Thirdly, our government should make realize the Act of protections for our worker in foreign states. This Act will make the protections for our citizens abroad (especially our migrant worker) become optimal; Fourthly, Our officers in abroad that have duty to give citizens services do they job as well as they should do. If our government (officers) can optimize their duty to give and access and services to their countrymen, I do believe with or without MCN we can fulfill the protections for our citizens abroad; Fifthly, Good diplomacy from our diplomats or consul is much needed. Because with or without MCN if we does not have good diplomacy its means nothing. 
As we know the point of international relations is diplomacy; and Sixthly, at least the repercussion study is really needed to know more about this Mandatory Consular Notification.

\section{REFERENCES}

\section{A. Book}

Ak., Shaymin, 1998, Hukum Diplomatik Suatu Pengantar, Armico, Bandung.

B. Sen, 1979, A Diplomat's Handbook of International Law and Practice, Martinus Njhoff Publishers, London.

Choi, Won-Mog, 2006, Diplomatic and Consular Law in the Internet Age, in book of Singapore Year Book of International Law and Contributors, Sybil.

Suryonokusumo, 1995, Hukum Diplomatik Teori dan Kasus, Alumni, Bandung.

\section{B. Journal Articles}

Beilke, Kristin K, "The U.S. is Not Alone in its Reluctance to Adhere to Supranational Decisions from the International Court of Justice", Loyola University Chicago International Law Review, Vol. 7, Issue 2, 2010.

Buys, Cindy Galway, et al., "Do Unto Others: The Importance of Better Compliance with Consular Notification Rights", Duke Journal of Comparative \& International Law, Vol. 21, No. 461, 2011.

Duffy, Edward W., "The Avena Act: An Option To Induce State Implementation of Consular Notification Rights After Medellin", The Georgetown Law Journal, Vol. 98, No. 795, 2010.

Hardono, Djoko, "Perlindungan Warga Negara Dalam Perbandingan", Jurnal Hukum International, Vol. 30, No. 1, 2003.

Kolesnikov, Yury A., "Meddling with the Vienna Convention on Consular Relations: The Dilemma and Proposed Statutory Solutions", McGeorge Law Review, Vol. 40, 2009.

Nicole M. Howell, "A Proposal for U.S.
Implementation of the Vienna Convention's Consular Notification Requirement", UCLA Law Review, Vol. 60, No. 1324, 2013.

Thontowi, Jawahir, "Kewenangan Daerah Dalam Melaksanakan Hubungan Luar Negeri (Studi Kasus di Propinsi Jawa Barat dan DIY)", Jurnal Hukum, Vol. 16, No. 2, April 2009.

\section{Papers/Speeches}

Cary Sims, John, et al., "Representing Foreign Nationals: Emerging Importance of The Vienna Convention on Consular Relations as a Defense Tool", Paper, Mid Level Diplomatic Course Batch XXXV Center for Education and Training Department of Foreign Affairs Republic Indonesia, Jakarta, 08 Agustus 2006.

Departemen Luar Negeri Direktorat Perlindungan WNI-BHI "Mandatory Consular Notification", Paper, Sosialisasi Perlindungan Hukum WNI dan BHI di Luar Negeri, Padang, 12 September 2006.

Husin, Sukanda, "Perlindungan Hukum Tenaga Kerja Indonesia (TKI) di Luar Negeri”, Paper, Seminar Sosialisasi Perlindungan Hukum WNI dan BHI di Luar Negeri, Padang, 12 September 2006.

Rofita, 2006, "A Concept for The Protection of Indonesian Citizens and Properties Abroad", Paper, Mid Level Diplomatic Course Batch XXXV Center for Education and Training Department of Foreign Affairs Republic Indonesia, Jakarta, 08 Agustus 2006.

\section{Internet Article}

Cary Sims, John and Linda E. Carter, "Representing Foreign Nationals: Emerging Importance of The Vienna Convention on Consular 
Relations as a Defense Tool", http://www. nacdl.org/CHAMPION/ARTICLES/98sep01. htm, accessed on 10 July 2012.

Wirayuda, N. Hassan, "Refleksi 2003 dan Proyeksi 2004 Departemen Luar Negeri Republik Indonesia", http://www.kbri-canberra.org.au/ speeches/2004/040106menlu.htm, accessed on 21 July 2012.

\section{E. Legislation}

Keputusan Menteri Luar Negeri Republik Indonesia Nomor SK.582/BU/III/79/01/TH 79 tentang Susunan Organisasi Perwakilan-Perwakilan Republik Indonesia di Luar Negeri.

Vienna Convention on Consular Relation 1963. 